\title{
Free Flying and China Dream
}

\author{
Jianchang $\operatorname{Han}^{1} \& \mathrm{Yi} \mathrm{Hu}^{2}$ \\ ${ }^{1}$ Northwestern Polytechnical University, Humanities, Economic \& Law College, Xi'an, PR China \\ ${ }^{2}$ China Aviation Industry General Aircraft Co., Ltd. Zhuhai, China \\ Correspondence: Jianchang HAN, Northwestern Polytechnical University, Humanities, Economic \& Law \\ College, Xi'an 710072, PR China. Tel: 86-133-9299-9566. E-mail: hjc13709120075@126.com
}

Received: August 27, 2015 Accepted: September 7, 2015 Online Published: September 21, 2015

doi:10.5539/ass.v11n26p212 URL: http://dx.doi.org/10.5539/ass.v11n26p212

\begin{abstract}
This paper reviews the development of general aviation and aviation culture, discusses the connotation and spiritual features of aviation culture, and puts forward the idea that free flying aviation culture can promote the free and comprehensive development of human beings. Through the presentation the national aviation culture craze in the United States, and investigation of the overall progress of low-altitude airspace management reform and the enforcement of people's aviation consciousness in China, the paper proposed that "Flying Dream" is the very reflection of "China Dream" in essence, and. It is concluded that to develop general aviation in China is a realistic demand of social progress and comprehensive development of human beings.
\end{abstract}

Keyword: aviation culture, china dream, free flying

\section{General Aviation and Aviation Culture}

Since ancient times, human beings created different mythologies about flying, like Chang'e a fairy lady who can fly to the moon and lives there in ancient Chinese myth, or Prometheus in Greek myth who can fly to steal the fire for humans, which are the very reflection of human beings' longing and imagination of flying. And the effort to realize the flying dream has never quitted. Our ancestors tried various methods to get closer to the dream of flying like free birds, from kite to wooden bird, from hot-air balloon to airship, and from glider to aircraft.

In 1903, with the birth of the first powered aircraft made by the Wright Brothers in the United States, Man entered the era of aviation. Aviation began to play more and more important role in people's life. However, general aviation is the most widely applied aviation. American scholar John J. Sheehan classifies all air operations as three types - commercial aviation, air operation and general aviation. General aviation also known as GA is further defined as aviation operation except commercial aviation and air operation, including private flight, business flight, and training flight, etc (Sheehan, 2006).

In the United States and some other countries, with the advent of aviation activities, the general aviation is booming vigorously. People can fly a small aircraft for travel, which has become an effective means of transportation and a kind of leading life fashion for them. At the same time, aviation culture has gradually grown to be an important part of social culture in Western countries. In some aviation superpowers, the general aircraft operated by individuals takes up a large portion of aircraft operation activities.

In China, though individual flight is just emerging in recent years but which has shown a new cultural vitality in itself and is becoming a kind of social trend and development orientation.

\section{Aviation Culture and the Free and Comprehensive Development of Human Beings}

\subsection{Free Spirit Is the Core of Aviation Culture}

British anthropologist Taylor defines culture as a “...complex whole which includes belief, art, morals, law, custom, and any other capabilities and habits acquired by man as a member of society" (Taylor, 1992). Aviation culture is the sum of the spiritual cultures generated in the aviation practices, with focus on the free flying which is the core of value, behavior, social atmosphere and other culture elements, and the results of interactions between these elements.

The spirit feature of aviation culture as its most key core is the free spirit. The pursuit of free flying and the longing for free life is the eternal pursuit of human beings. Because the yearning for freedom lies in the deep root 
of human nature, so people ride on horse, develop carriage and car for faster travel instead of totally relying on walking. Faster to get to other places helps people to explore many other places and leaves them more time to think and create. If we say the on-ground vehicles expanded people's activity scope in horizontal direction, then going up to the sky, flying did that in lateral direction. With flying, not only the traveling speed fastened, range widened, but also things they can see and experience are enriched. Behind these inventions lies the heart to free himself from physical and spiritual constraints around him.

Most inventions in human history are the products of human's searching for freedom. Therefore, we can say freedom is the source of innovation as well as the fundamental force of social progress. "Wherever there are any free personalities, there are any independent progress centers." (Mill, 1982) Freedom is the core value of the western culture, which obviously plays as the cultural root for rapid development of general aviation in western countries.

Meanwhile, freedom is also the core value of scientific socialism. In the Report of the Eighteenth National Congress of the Communist Party of China, it is stated that "we should promote prosperity, democracy, civility, and harmony, uphold freedom, equality, justice and the rule of law and advocate patriotism, dedication, integrity, and friendship, so as to cultivate and observe core socialist values." ( $\mathrm{Hu}, 2012)$ Spirit of freedom has always been the significant value advocated by Chinese Society.

\subsection{Aviation Culture Promoting Free and Comprehensive Development of Human Beings}

Karl Marx advanced the theory of man free comprehensive development, took the "free development of each human" as the purpose of human development, "the free self-development of each would be the condition of the free self-development of all." (Marx \& Engels, 1974)

The future society is "a social form based on the basic principle of everyone's complete and free development." (Marx \& Engels, 1995)

Friedrich Engels emphasizes the cause of culture making human free, "each progress in culture is a step toward freedom." (Marx, 1975)

The author believes that free flying spirit of general aviation can promote the free and comprehensive development of human being. Flying generates great influence in people's life. Travel at high speed brings great convenience for humans as well as the liberation of spirit at the same time. On the one hand, free flight help to facilitate the development of human activities, needs and abilities; and on the other hand, free flight can break previous restriction on human social relations caused by geographical natural environment, enriching people's social relations, which in return helps people to reach an all-round and free development of their personalities and capabilities, and to use their talents to the maximum, and which in the end will essentially promotes mankind's free and comprehensive development.

Human modernization is the kernel of Chinese traditional culture's modernization transition. Social modernization ultimately points to the comprehensive development of human, and man modernization is the final purpose and destiny of social modernization. American sociologist Alex Inkeles once described that a nation, only when its citizens have transited to modern man both psychologically and behaviorally, then can be called a modern nation (Inkeles, 1985). Due to aviation activity's modern feature and its influence on people's behavior and attitude towards life, general aviation plays a positive role in the modernization transition of Chinese traditional culture and becomes a powerful driving force of human modernization at the same time. Therefore, generally speaking, to develop general aviation culture will become a very effective way to facilitate the modernization transition of Chinese traditional culture and human beings, which will eventually promotes the free and comprehensive development of human being.

\section{Aviation Culture Craze in the United States}

Marx Webb points out: "Behind any cause exists some spirit power deciding the development direction and fate of the cause." (Weber, 1987) American aviation culture value overwhelmingly highlights the social philosophy of democracy, freedom, and fairness.

In America, flying is a kind of life attitude and life style, and which also gradually evolved to be a kind of social culture. Based on statistics we have by now, there are nearly 230,000 general aviation aircrafts, 700,000 pilots in the United States, and approximately 20,000 general aviation airports as well. There is also a program organized by EAA (Experimental Aircraft Association) in America, the Yong Eagles program. In this program, the members of EAA are encouraged to volunteer in taking millions of children aged from 8 to 18 to fly in the sky, with the aim of taking them to experience the fun of flying and to inspire their passion for aviation (Xu, 2000). 
As mentioning American modern transportation vehicle which usually refers to two types, one is car, the other is plane. The Americans advocate freedom, encourage innovation. They enjoy the loose social environment and the sound service system at the same time, own the world's leading Air and Space Museums and the ubiquitous aviation cultural atmosphere, and have developed a kind of craze about aviation across the whole country. For them, designing aircraft, assembling aircraft, collecting airplanes, flying an airplane is an America fashion that has lasted for a century.

According to statistics, there are about 600 fly-in communities and airparks spread across the United States so far. Each family owns an aircraft and everyone lives here loves flying (Yan, 2008). No matter what kind of career they have and no matter how old they are, they choose to live in fly-in communities just because their passion for flying. They can fly to work, to shop, to go sight-seeing, to meet friends, and etc. They enjoyed the free-to-go freedom without wasting time on booking tickets, waiting in the departure hall. Besides the freedom and highly effectiveness they have, sometimes they just enjoy the leisure time of fiddling with their aircrafts in the hanger, listening to the lyric-like thundering of aircraft engines. That's the deep-rooted passion and love for aviation which has penetrated to the blood and neurons of this nation. As is known to all, that American national aviation culture craze is the foundation for America growing to be the aviation power in the world.

\section{The Demand of General Aviation Development in China}

\subsection{Low-Altitude Airspace Management Reform}

Research shows that, when GDP of average per capita reaches more than $\$ 4,000$, there will be a breakthrough in the development of general aviation, and private aircraft will be affordable for most families. After the American per capita GDP reached $\$ 4,000$ in 1968 , the general aviation industry witnessed an explosive growth in its development.

In 2010, China per capita GDP was about US\$4,361, which had achieved the economic level of general aviation rapid development. But based on the simplified comparison of GA data in Table 1, it is obvious to notice the huge gap general aircraft status between China and America.

Table 1. GA data comparison between the U.S. and China

\begin{tabular}{ccc}
\hline Data/Country & U.S. & China \\
\hline GA airports & 19,729 & 300 \\
GA aircrafts & 209,034 & 3,857 \\
Pilots & 552,656 & 5,881 \\
FBO & $3000+$ & $5-6$ \\
Flight hours & $25 \mathrm{~m}$ & $5.17 \mathrm{~m}$ \\
\hline
\end{tabular}

* GAMA2013 General Aviation Statistical Databook \& 2014 Industry Outlook.

The significant impetus of general aviation for the social and economic development is crystal clear, for this reason the Chinese government has taken the general aviation development into the Twelfth Five-year Plan.

In September 2010, the Chinese government launched "On Deepening Reform of Low Altitude Airspace Management" to make the arrangement for the opening of airspace; about ten cities in China will be the first pilot places enjoying the initial opening of low-altitude airspace. Since then, the authority gradually issued several policies to facilitate the development of general aviation in China. In Oct 2014, the newly issued "The Regulation about Using and Managing Low-altitude Airspace" demonstrates government's determination to develop general aviation industry in China, and opens up a new prospect for it.

Within the strategic planning of CAAC, it is proposed that by 2020, general aviation will reach scale development level; total flying hours will get to 2 million hours with a $19 \%$ annual growth rate. Meanwhile, most GA companies are taking continuous effort to build up their ability in GA aircraft design, manufacture, to establish the sales and after-sales service center, to nurture GA market in China. Inspired by these favorable policies and positive measures taken by government, and the effort from GA companies, insiders all believe the future of general aircraft industry will be promising, and the smooth development of GA industry will be in the interest of the progress of Chinese society and well-being of the people. 


\subsection{A Questionnaire}

In August 2013, the author carried out a questionnaire survey on the longing for flying and private aircraft market demand in Guangdong China. Guangdong is an economically developed province in China, the frontier zone of the reform and opening up, and also the hometown of Feng Ru the first aircraft designer, manufacturer and aviator in China. The survey respondents were young entrepreneurs, high income people and aviation enthusiasts from Guangdong province. The total of 147 copies of questionnaires was issued, with 117 feedbacks and 81 valid ones. According to the survey results, 66 persons have clear intention of getting a private flying license, accounts for $45 \%$; and 80 persons dreamed of having a private aircraft themselves, which is about $54 \%$. There is also certain part of people take a wait-and-see attitude toward the popularity of private aircraft in China.

It is not difficult to notice from the survey that even though personal flying has a late entry in China, the dream of flying is inborn with the high-income population. The questionnaire results foretell that along with the all-round development of Chinese economic society, especially after the issue and implementation of the reform of the airspace control system, the emergence of a large number of private aircraft will be possible and Chinese flying dream will be realized.

\section{China Dream and Flying Dream Deadline}

In March 2013, Mr. Xi Jinping, the newly elected China's President, once interpreted Chinese dream by saying: "The Chinese people living in our great motherland and the great age shall all enjoy the opportunities of their brilliant life, enjoy a chance to have their dreams come true, enjoy the chance of growth and progress with China and the era." (Xi, 2013)

China aviation industry believes that "Flying Dream" is one of the embodiments of "China Dream". Therefore, only when general aviation is grounded and become popular in China and the free flying dreams come true, can the dreams of China becoming an aviation superpower and the great rejuvenation of the Chinese nation be truly realized.

In recent years, the Chinese Government has issued a series of plans and policies, a lot of capital is flowing into general aviation industry, small aircraft manufacturers are appearing constantly, flight training schools are springing up like mushrooms, and there are regional aviation exhibitions and air shows every month, from which we can tell that private flight is beginning to enter the Chinese people's life. It is predicted that in 2020, the number of general aircraft in China will be increased from two thousand now to more than 10,000 aircrafts and general aviation culture will quickly gain popularity in China.

\section{Conclusion}

Culture is a reflection of social existence as well as the condensation of lifestyle. The free flying spirit of aviation culture promotes the development and prosperity of our society. With the advance of economic development and reform, the spring of rapid China general aviation development is around the corner. The government is accelerating low-altitude airspace reform, establishing facilities and infrastructures, providing policy support and forming service awareness. In addition, Chinese people are increasingly to have better conscious of aviation and deeper yearning for flying. Along with the growing social atmosphere and value of aviation, these favorable factors just mentioned will definitely together lead the development of general aviation to prosperity in China. Aviation culture of free flying can satisfy the people's needs, change people's life, and promote the free and comprehensive development of human beings.

\section{References}

Sheehan, J. J. (2006). Business Aviation Operation and Management - Air Travel Arranged as Demands. Beijing: Aviation Industry Press.

Taylor. (1992). Primitive Cultures. Shanghai: Shanghai Literature \& Art Publishing House.

Mill, J. (1982). On Liberty. Beijing: The Commercial Press.

Hu, J. T. (2012). Firmly March on the Path of Socialism with Chinese Characteristics and Strive to Complete the Building of a Moderately Prosperous Society in All Respects. People's Daily.

Marx, K., \& Engels, F. (1974). Complete Works of Marx and Engels: Volume 39 (Part I). Beijing: People's Press.

Marx, K., \& Engels, F. (1995). Selected Works of Karl Marx and Friedrich Engels (Vol. 4). Beijing: People's Press.

Marx, K. (1975). Das Kapital (Volume I). Beijing: People's Press.

Inkeles, A. (1985). Exploring Individual Modernity. Sichuan People's Publishing House. 
Weber, M. (1987). The Protestant Ethic and the spirit of capitalism. Translated by Yu Xiao et al. Beijing: Sanlian Bookstore.

Xu, Y. K. (2000). North American Flight Training. International Aviation, (11), 30-31.

Yan, J. (2008). The U.S.A.: Flight Community Flight Dream. Economic Information Daily.

Xi, J. P. (2013). Speech at the Closing Ceremony of the Twelfth National People's Congress. People's Daily.

\section{Copyrights}

Copyright for this article is retained by the author(s), with first publication rights granted to the journal.

This is an open-access article distributed under the terms and conditions of the Creative Commons Attribution license (http://creativecommons.org/licenses/by/3.0/). 